Potravinarstvo Slovak Journal of Food Sciences

vol. 13, 2019, no. 1, p. 971-983

https://doi.org/10.5219/1201

Received: 20 September 2019. Accepted: 21 October 2019.

Available online: 28 December 2019 at www.potravinarstvo.com

(C) 2019 Potravinarstvo Slovak Journal of Food Sciences, License: CC BY 3.0

ISSN 1337-0960 (online)

\title{
DEVELOPMENT OF GLUTEN-FREE NON-YEASTED DOUGH STRUCTURE AS FACTOR OF BREAD QUALITY FORMATION
}

\author{
Olga Shanina, Ivan Galyasnyj, Tetyana Gavrysh, Kateryna Dugina, Yuriy Sukhenko, \\ Vladyslav Sukhenko, Natalia Miedviedieva, Mikhailo Mushtruk, \\ Tatyana Rozbytska, Natalia Slobodyanyuk
}

\begin{abstract}
The article is devoted to the study of the influence of hydrocolloids and animal protein concentrates on the formation of the foam-like structure of gluten-free non-yeast dough as the main factor for bread quality formation. The use of CMC in a concentration of $0.5 \%$ is found to be appropriate. The bread volume increases to $236 \mathrm{~cm}^{3} .100 \mathrm{~g}^{-1}$ in comparison with the control sample in water $-202 \mathrm{~cm}^{3} .100 \mathrm{~g}^{-1}$. It is proved that the suggested additives in the amounts of $0.5-1.0 \%$ Helios-11 and $0.5 \%$ CMC solution cause $100 \%$ resistance of egg white foam. In this case, the foaming ability increases with the addition of Helios-11 only in amounts up to $1.0 \%$, then decreases for higher amounts of Helios-11 or in the presence of CMC. This can be explained by the increase in density of the whipping mass and the ability of both additives to thicken solutions. In the presence of the additives, the foamy texture of the dough changes. The number of large pores $(0.7-1.5 \mathrm{~mm})$ decreases almost fourfold, and the number of small and very small pores $(0.1-0.5 \mathrm{~mm})$ increases significantly. The index of form resistance of the control sample is 32, and in the presence of $0.5 \% \mathrm{CMC}$ with $0.5-1.0 \%$ APC is $20-21$, which indicates a decrease in the surface tension of the aqueous solutions with additives, to a large extent, in the case of joint use.
\end{abstract}

Keywords: gluten-free; non-yeast; CMC; APC; dough structure

\section{INTRODUCTION}

Gluten-free products have a vital role in the prophylactic and curative diet of coeliac disease patients, and are crucial products for consumers with a variety of nutritional disorders such as gluten allergy or intolerance.

According to the World Organization of Gastroenterology, the global prevalence of coeliac disease is at least $1 \%$, but varies greatly between countries. There are no accurate statistics on the incidence of the disease in Ukraine, which is connected to the complexity of diagnosis, but the number of people suffering from coeliac disease and gluten intolerance ranges from 400 to 500 thousand (Kraievska and Stetsenko, 2018; WGO, 2016) and even more.

The world medical community, food industry experts and public organizations are paying close attention to methods for identifying gluten in foods, and at the same time simultaneously providing consumers with all the necessary information about its content in certain foods (Scherf and Poms, 2016).

Unfortunately, the problem of giving prior and objective information to consumers about the content of gluten in products in our country receives practically no attention. On the contrary, the legislative base of the European
Union countries, the USA, Canada, etc. demands that food manufacturers and employees of the trade networks clearly label products with the sign "Gluten-free" (Rizkalla Reilly and Green, 2012).

Technologies are being developed and the production of gluten-free bread, pasta, biscuits, muffins, pastry flour and others is being set up in many countries for patients with coeliac disease. These products are marked on their packaging with a "crossed grain" symbol. During their production, special attention is paid to the purity of the raw grain materials, from which the smallest impurities, which may be toxic for patients with coeliac disease, should be removed (Rosell, Bajerska and EI Sheikha, 2015).

Compared to the countries of North America, Europe, Japan, etc., in Ukraine the production of gluten-free products in sufficient assortment and volumes has, unfortunately, not been established. However, to provide this category of people with specialized dietary foods is a constant necessity.

Since May 2017, after the signing of a licensing agreement between the Association of European Coeliac Societies (AOECS) and the All-Ukrainian "Ukrainian Coeliac Union" and the registration of the "crossed grain" symbol in Ukraine, the licensing of Ukrainian producers 
has become possible. Permission to license gluten-free products within Ukraine has greatly simplified the procedure for assigning a corresponding symbol, which should positively influence the development of the domestic market of gluten-free products (Naumova, Doncova and Agramakova, 2017; Ukrainian Coeliac Society, 2019).

Bakery, confectionery and pastry flour products that do not contain gluten are one segment of this market. The range of gluten-free flour products in the Ukrainian market is formed mainly by imported products, which are fairly expensive. In addition, most gluten-free products in Ukraine are flour confectionery or baking mixtures, which can be used at home.

It is clear that for consumers the preparation of glutenfree food products is primarily a dietary matter. But in the production of gluten-free bakery products, the exclusion of gluten becomes a serious technological challenge and requires the solution of a number of technological problems. During the last decades, many studies have been conducted to improve the quality of gluten-free bread and its nutritional properties. However, there are still some issues with the development of gluten-free bread with a satisfactory structure, shelf life and cost.

Given the foregoing, not only the development of safe and effective therapeutic and dietary alternatives is justified, but also new approaches to the detoxification of gluten or gluten-free compositions. In addition, there is an obvious need for the development of formulations and technologies for the production of gluten-free flour products that have sufficient quality and an affordable price.

Investigations by specialists in the world food industry are aimed at finding gluten-free basic and additional raw ingredients (hydrocolloids, protein components, starches, pseudo-cereal raw materials, etc.), as well as the development of new technological approaches that involve the use of enzymes, high pressure, hydrothermal treatment, extrusion and sprouting of grain and flour raw materials, dough souring, etc. Each ingredient has a special role in gluten-free bread baking.

Rice flour and rice starch, corn flour and corn starch, potato, manioc and wheat starch are the most common and widely used raw ingredients (Dotsenko et al., 2019; Morais et al., 2014; Mancebo et al., 2015; Gómez and Sciarini, 2015). As alternative raw materials, gluten-free flour from cereals (sorghum, millet, oats) (Trappey et al., 2014; Marston, Khouryieh and Aramouni, 2014) gluten-free flour from pseudo-cereals (buckwheat, amaranth, quinoa); flour from roots and tubers (cassava, sweet potatoes); legume flour (soybean, chickpeas, conifer, beans, lentils, peas); other flour (linen, chestnut, banana, teffi, etc.) (Hager and Arendt, 2013; Mariotti, Pagani and Lucisano, 2013; Korus et al., 2015; Aguilar et al., 2016; Aguilar et al., 2015) as well as flour mixtures are offered.

Starch and protein components are important because they cause the transformation of gluten-free dough as a foam-type system to the bread system (Nitcheu Ngemakwe, Le Roes-Hill and Jideani, 2014). Since gluten-free bread contains a large amount of starch, the beginning of bread firming is faster than that of bakery products containing gluten. The origin of the starch (in particular, the size of the starch granules, the ratio of fractions, chemical and physical modifications) significantly influences its technological behaviour in terms of the ability to swell, water-binding, and the rate of gelatinization-retrogradation. This, in turn, is related to the rheological properties of the dough, the structure of the bread and the terms of its storage (de la Hera, Martinez and Gómez, 2013).

Also, dietary fibres are considered as a special raw material for gluten-free bread production. As a rule, the higher the amount of dietary fibre in the dough, the greater the amount of water needed to obtain dough of a given consistency. In gluten-free bread production, the amount of water used to make the dough is often practically the same as (or more than) the total number of dry recipe ingredients.

Fibres can play a positive role in gluten-free bread quality. Psyllium is a generic name for several Plantago family members whose seeds are used for the commercial production of gum-substances (Pal et al., 2019). Psyllium develops a "weak gel" network that captures carbon dioxide formed during fermentation, and therefore increases the gas content and bread volume. This bread is stable at different $\mathrm{pH}$ and temperature levels and is similar to gluten. Therefore, Zandonadi and co-authors suggested replacing gluten with Psyllium in gluten-free dough (Puppin Zandonadi, Braz Assunção Botelho and Coelho Araújo, 2009).

It has been established that soluble Psyllium can play a crucial role in the development of gluten-free bread quality, as well as in its ability to form a film and to detect the anti-inflammatory effect, which it has due to its high water-binding ability. Its technological effect and functional properties can be enhanced in the presence of other additives (Cappa, Lucisano and Mariotti, 2013).

The use of hydrocolloids together with thickeners or stabilizers, such as gum arabic, carboxymethylcellulose or guar gum, opens up significant prospects for the creation of alternative gluten-free products that are not worse in quality than those containing gluten.

Hydrocolloids are widely used as structuring agents to simulate the visco-elastic properties of gluten. These ingredients are generally used as a substitute for gluten due to their thickening ability, high water-binding and gelforming characteristics. They are able to control the properties of the water phase, and stabilize the structure of emulsions, foams, suspensions and multiphase systems (Morreale, Garzón and Rosell, 2018).

Hydrocolloids increase the volume of the dough, stabilizing its foam structure by increasing its viscosity, flocculation and coalescence. Hydrocolloids also prevent the influence of the water phase on the foam structure, improving the stability of the fluid in the films surrounding gas bubbles. Hydrocolloids can significantly affect the behaviour of the dough, even if they are present in very small amounts (Moreira, Chenlo and Torres, 2012).

Proteins play a crucial role in determining the structure of many foods, including gluten-free bread (Ziobro et al., 2013). Due to their specific functional properties, proteins of animal origin are widely researched and offered for use in food systems.

One review (Deora, Deswal and Mishra, 2014) aims to highlight the role of alternative protein components that 
can be used to develop gluten-free products both functionally and nutritionally. There is enormous potential for the incorporation of proteins from various sources (dairy products, cereals and legumes) to improve the nutritional value of gluten-free products in addition to structural and texture-forming properties. In particular, the range of food proteins used in the development of glutenfree products include the following: soybean protein isolate, pea protein isolate, milk protein isolate, rice protein isolate, whey protein, egg white protein, zein protein, yeast protein, casein, albumin, kafirin, carubin etc.

An important functional component of the gluten-free bread formula is enzyme preparations. The paradigm of modern enzymatic modification of gluten-free bread is aimed at changing the structure of the dough by hydrolysis, oxidation or cross-linking, which leads to an improvement in the structure of the crumb, the quality of the fresh bread, and also predetermines the extension of shelf life (Renzetti and Rosell, 2016).

The addition of guar gum and microbial transglutaminase leads to greater stability of gluten-free dough to the mixing process. The network of proteins formed becomes similar to the structure formed in the presence of gluten. The addition of transglutaminase has a positive effect on the yield of dough and the maintenance of moisture in the bread after baking. Negative effects of transglutaminase on the specific volume of bread may be levelled by the addition of guar gum (Mohammadi et al., 2015).

It should be noted that the majority of the analysed scientific works concerning the improvement of glutenfree bread technology are devoted to the relevant issues of its production using yeast as a dough loosener. In other words, the rheological properties of such dough masses should ensure the maximum keeping of gas bubbles throughout the dough preparation, as well as in the first stage of baking.

In the technology of gluten-free products the main problem of creating high-quality goods is the absence from flour raw materials of a unique structure-forming agent gluten. Because of this, the gas-forming ability of the dough significantly decreases, especially during prolonged fermentation. Despite the sufficient activity of yeast in gluten-free dough, the effectiveness of this method of dough loosening is very low. All technological efforts are aimed at keeping carbon dioxide during dough making (fermentation, proofing, etc.).

In other words, the active course of the sugar fermentation process and the formation of carbon dioxide in gluten-free dough is almost completely levelled off. Because its accumulation in dough is ineffective, since after the maximum stretching the dough is under the action of the generated gas, a continuous network ruptures, and as a result, the dough loses volume. All this leads to an increase in the loss of the dry matter of the dough fermentation continues, and the gas is not retained.

In our opinion, another technological concept is needed for the production of gluten-free non-yeast dough. It is necessary to ensure, firstly, the maximum foaming capacity of the recipe mixture, and secondly, the maximum resistance of such foam during the short development of the dough (placing the dough in the baking moulds) and at the initial stage of baking. That is, to improve the porous structure of gluten-free non-yeast bread, another, nonmicrobiological method of loosening is needed.

Information on this issue is extremely limited in the sources investigated. In the absence of a microbiological leavening agent (yeast), enzyme preparations can be used. So, for gluten-free bread, (Marti et al., 2015) suggest using gluten inoculum in a mixture with gluten-free flour (1:1), which should be mixed with water. The fermentation stage lasts about 15 hours. The inoculum is obtained directly from the usual wheat yeast dough, which is kept in spring water for 24 hours. The dough is then dried and, together with water enriched with microorganisms, they are added to gluten-free flour raw materials. Then the dough is fermented for 24 hours. A refreshment step is recommended to be repeated every day at least five times. This study shows that from wheat fermented dough glutenfree dough can be obtained that is suitable for bread production without the addition of yeast or lactic acid bacteria, since the inoculum already contains live and viable microbial strains (lactic acid and yeast). However, in our opinion, it is possible to call this a non-yeast product only conditionally. This method of bread production is similar to that used in the production of sourdough or predough. In addition, one of the obstacles to widespread adoption of this technology is its complexity and long-term sustainability

To obtain a porous structure of bread without the use of yeast, a whipping operation can be used. In this area of focus, a number of papers have been published by (Magomedov, Ponomareva and Aleynik, 2008). Thus, it is suggested to mix a dough using whole wheat flour, an enzyme preparation "GC-106" - (Döhler, Germany) fungal protease produced by Aspergillus oryzae in the amount of $0.008-0.012 \%$ to the mass of flour, citric acid, salt and drinking water. Dough-making is carried out in two stages: first, all the recipe ingredients are mixed in the kneading chamber for $8-10$ minutes, at $45-55^{\circ} \mathrm{C}$, then air is supplied to the chamber with a pressure of $0.35-0.45 \mathrm{MPa}$ and the dough is kneaded for $6-10$ minutes. The authors claim that this helps to increase the yield of the finished products, to obtain whipped non-yeast products with high nutritional and biological value, to slow down the process of bread firming, and to intensify the process of dough preparation. Analysing such a suggestion, one notes the complexity of the process flow diagram and the use of wheat as a grain raw material.

Another area of focus in non-yeast bakery is extrusion technology. The extrusion of supercritical fluid (SCFX) allows us to continuously produce non-yeast dough by the inclusion of supercritical carbon dioxide (SC-CO2). In this study (Ruttarattanamongkol, Wagner and Rizvi, 2011), the optimal formation of dough, production and baking were developed. The combination of vacuum and common baking is recognized as an approach that can be useful for the continuous production of dough and the finished product. The total duration of dough-making is less than 1 hour and during proper baking the entire process can be continuous. The authors believe that since no yeast is present, no ethanol is emitted. And this means the absence of harmful volatile organic emissions and no need for an expensive catalytic converter. 
In our opinion, the relevant area of the research focus in gluten-free non-yeast bread technology is the use of physical (whipping) and chemical (using chemical baking loosening agents) methods of dough loosening or their combinations, using improving additives such as sodium carboxymethyl cellulose (CMC) and animal protein concentrates (APC).

\section{Scientific hypothesis}

We assume that exclusion of dough fermentation stage will reduce the loss of carbon dioxide released during fermentation, prevent a decrease in volume of bread and formation of cracks on crust of baked product. In this case, it is necessary to prove the possibility of foam-like structure formation by mechanical whipping of gluten-free dough for the production of yeast-free bread. Therefore, the tasks were to study the surface properties of waterflour suspensions and the structural-mechanical properties of dough in the presence of improving additives, as well as the effect of CMC and APC on the quality of gluten-free non-yeast breads.

\section{MATERIAL AND METHODOLOGY}

During the experimental research and production testing, the following products were selected: flour mixture of "rice flour:corn flour - Frice:Fcorn" in the ratio of 70:30\% (rice flour TM World's Rice; corn flour TM "Skvyryanka"); carboxymethylcellulose sodium salt (CMC - SMS 6500); animal protein concentrates (APC - Helios11 and Scanpro T95); sodium bicarbonate (baking soda); model systems based on egg protein; gluten-free non-yeast breads; gluten-free non-yeast dough with various kneading options. The obligatory general quality indices of all these products correspond to the indicators of the current normative documentation.

The dough was mixed in various ways. Kefir (a source of high quality animal protein that is well absorbed and is able to enrich dough with lactic acid) was used as a liquid phase of the dough in variant 1. Rice-corn flour mixture was used as a flour raw material. Chicken egg and sodium bicarbonate were used as the dough loosener. In addition, sugar and salt were used. The dough loosening used a combined method (mechanical and chemical). Kneading by variant 2 used a $0.5 \%$ aqueous solution of $\mathrm{CMC}$ as a liquid phase. The dough loosening method was mechanical. APC was used as a technologically active recipe component in variant 3 . This additive has good foam-forming and stabilizing properties. The dough loosening method was also mechanical. Variant 4 provides a combination of CMC and APC, which could improve the formation process of gluten-free non-yeast dough at the expense of a more developed and stable dough mass. The dough loosening method is mechanical.

The volume of finished products was measured by a volume meter. Baking loss was defined as the difference between the weight of the dough and the hot bread in percentage. Bread shrinkage was defined as the difference between hot and cooled bread.

The foam-forming ability of egg protein (FFA) and foam resistance (FR) were determined by the Lourie method (Tikhomirov, 1975). Research of the dough foam structure was carried out as follows. A sample of dough was prepared according to the recipe, a portion of dough was poured into a cuvette, made of optical glass K-8 on the technology of UV bonding with an internal size of $20 \mathrm{~mm}$. The sample was photographed in macro mode. The resulting photos were processed using the Photo M 1.21 program, calculating the amount and pore area of a certain size, the total area of pores, total area of dough, ratio of pore area to total dough area, and ratio of total area of pores to the total area of dough.

To determine the surface properties of the water-flour suspensions, we used the lying drop method (Gorelov and Dranchuk, 2003). The diameter of the drop (in several repetitions) was $6 \pm 1 \mathrm{~mm}$; this ensures that the edge angle will not depend on the diameter, since it is known that, in the case of very small droplets, the influence of the surface tension of the liquid itself (the tendency towards the formation of a spherical drop) is significant, and in the case of large droplets, the forces of gravity begin to dominate. By this method, the angle between the solid surface and liquid at the point of contact of the three phases was measured.

Additionally, a graphical method for determining the shape resistance (H/D) of the drop was used - due to the ratio of the height of the drop to its diameter.

\section{Statistical analysis}

Approximation of the obtained experimental data was carried out using the least squares method, as well as the MATHCAD mathematical package and EXCEL spreadsheet packet. The degree of credibility for all experiments is 0.95 .

\section{RESULTS AND DISCUSSION}

Additives of polysaccharide (CMC, brand SMC 6500) and a protein nature (APC, namely Helios-11 and Scanpro T95) were chosen as enhancers of the gluten-free nonyeast dough structure. Hydrocolloids were used to increase the viscosity of the dough, and stabilize the distribution of the ingredients by preventing accumulation and foam destruction. These can significantly affect the behaviour of the dough, even if they are present in very small quantities. As was shown in the research (Lazaridou et al., 2007; Sabanis, Lebesi and Tzia, 2009) improvement of the specific volume of gluten-free bread from rice flour by the inclusion of gums, pectin, carboxymethylcellulose, agarose, xanthan or oat $\beta$-glucan was analysed previously. It was found that addition of insoluble fibres to gluten-free formulations significantly increased the bread volume.

At the first stage of the study, the concentration of CMC was chosen as the variation factor. It was also considered necessary to investigate the expediency of simultaneous use of another recipe component, namely bicarbonate sodium (baking soda), as a loosener. Experimental samples were prepared according to variant 2 of dough making without and with added soda. The water temperature was $30{ }^{\circ} \mathrm{C}$. The composition of the flour mixture is "Frice:Fcorn" at 70:30\%. The results of laboratory baking are presented in Table 1 and Figure 1.

It can be seen that the use of CMC in a concentration of $0.5 \%$ is appropriate. The bread volume increases to $236 \mathrm{~cm}^{3} \cdot 100 \mathrm{~g}^{-1}$ compared with the control sample with water $-202 \mathrm{~cm}^{3} .100 \mathrm{~g}^{-1}$, a difference of $15 \%$. According to the experimental data, the combined use of $\mathrm{CMC}$ and 
baking soda is unsuitable, as it leads to excessive loosening of the crumb structure and weakening of its carcass.

An unbroken dough network develops, part of the gas gets lost, and the specific volume reduces. In addition, the colour of the crumb gets noticeably darker, and folds are formed on the lateral surface of the breads. The concentration of $0.7 \%$ of $\mathrm{CMC}$ is also considered to be excessive, as it leads to some deterioration in the structure of the breads.

Addition of non gluten proteins in the production of glutenfree bread is especially interesting, as those substances have both nutritional and technological role. Their addition reduces amino acid deficits, and impact structure and texture forming properties of the dough, as well as the color and sensory properties of the final product, in this way affecting its consumer acceptance. Their presence may influence storage of glutenfree products, and decrease bread staling. Protein could be added in various forms, as components of gluten-free flours (e.g., rice, soy, pea) or in the form of concentrates and isolates (Deora, Deswal and Mishra, 2014). The formation of dough and bread structure by protein addition is often assisted by the introduction of other supplements such as polysaccharide hydrocolloids, enzymes or surfactants. Among cereal proteins zein and kaffirin have been applied for gluten-free bread supplementation (Deora, Deswal and Mishra, 2014; Pontieri et al. 2013; Schober et al. 2011; Phongthai, 2016). Andersson et al. (2011) observed that the addition of corn protein in the presence of hydrocolloids positively influences dough rheology, improves bread structure and increase its volume.

The results of the study of the influence of animal protein concentrates on the specific volume and sample height (without $\mathrm{CMC}$ and with $0.5 \% \mathrm{CMC}$; water temperature $30{ }^{\circ} \mathrm{C}$ ) are shown in Figure 2. Analysis of the dependencies indicates the positive effect of APC on the structural and mechanical properties of the breads. In particular, the specific volume of the bread improves to a greater extent without the use of CMC. This can be explained by the high hydration power of CMC and its ability to increase the moisture retention capacity of the dough. Therefore, even with higher values of the products volume (confirming the fact that the height of the products is maximal when APC is added together with CMC), their mass is also slightly increased, but the specific volume decreases (the "APC + CMC" curves on the graphs are located lower than the APC curves).

It should be noted that the differences between these indicators are very small. However, the combined use of additives changes the structure of the bread - it becomes more elastic and less fragile when slicing and chewing. For the use of APC as an enhancer of gluten-free non-yeast dough, it is necessary to limit its concentration within the range of $0.5-1.0 \%$ to the mass of flour (higher concentrations lead to a slight deterioration of the structural and mechanical properties of the crumb, and are also inappropriate from an economic point of view).

The influence of the $\mathrm{CMC}$ concentration on the specific volume and height of samples (without APC and applying $1.0 \% \mathrm{APC}$ ) was also investigated. We can interpret the data obtained as follows. When applying animal protein concentrates together with $\mathrm{CMC}$, similar tendencies are detected, irrespective of the type of additive; namely, increase of the hydrocolloid concentration contributes to a rise of the specific volume and height of the breads at the cross-section if the concentration of CMC does not exceed $0.5 \%$. Further, the structure of the products slightly deteriorates - the volume and height are reduced. Helios-11 has a slightly higher efficiency compared to Scanpro T95, but such advantage is not significant. In other words, any of the studied additives may be recommended for practical use. This approach will make it possible to take into account the availability of raw materials on the market and their market value for obtaining bakery products with a high competitive ability.

The proposed recipe components allow the exclusion both of yeast as a main ingredient of bread dough, and of long-term fermentation as the determining technological stage of dough making. The resulting technological effect requires a clear scientific justification. Considering this, in the next stage of the study, the foam-like structure of gluten-free non-yeast dough is studied.

In the production of traditional wheat bread, when the flour-water mixture turns into dough, gluten forms a viscoelastic network that can capture and retain gassed bubbles. The condition of dough aeration immediately after mixing has a huge impact on the texture of the bread. And the gassed architecture of the dough is regulated by various physical principles related to the formation of foam and stabilization. The specificity of the production of glutenfree non-yeast dough by whipping is that the resulting foam structure is exposed to unwanted external influences, which leads to a decrease in its stability. These factors include mixing the whipped mixture with flour and placing the dough in baking cups. In such conditions, it is important not only to get a foam system with given characteristics, but also to preserve it during the technological process. Accordingly, in our opinion, it is important to investigate the foaming ability and foam stability to fracture.

The suggested additives in the technology of gluten-free bread are intended to improve the properties of the flour protein substances in the absence of gluten proteins. To study its effect, the action of APC on the foaming ability and stability of egg foam without additives and with the addition of $0.5 \% \mathrm{CMC}$ solution (in the amount of $10 \%$ of weight of egg protein) at fixed whipping modes and a temperature of $20^{\circ} \mathrm{C}$ was investigated. At the same time, the foaming ability (FA) and foam resistance (FR) for an egg white + water model ( $10 \%$ by weight of egg protein) were studied. Usually, adding about $10 \%$ water to the weight of the egg white improves the foaming ability of the dough. Therefore, this precise amount was chosen for the control sample to minimize the effects of the water and to demonstrate the specific effects of the CMC additives.

In order to confirm the effective impact of the CMC, the improvement of FA and FR rates was expected in an egg white protein $+0.5 \%$ solution of CMC compared to an egg protein protein $+0.5 \%$ solution of CMC compared to the egg protein + water sample. The experimental data are presented in Figure 3. 


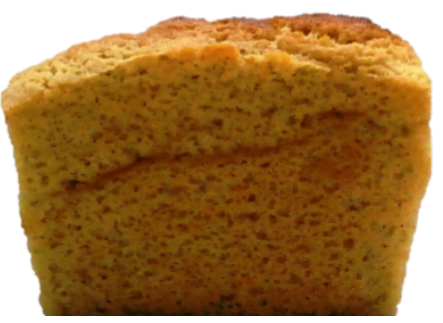

$0.3 \%$ CMC with soda (sample no. 1)

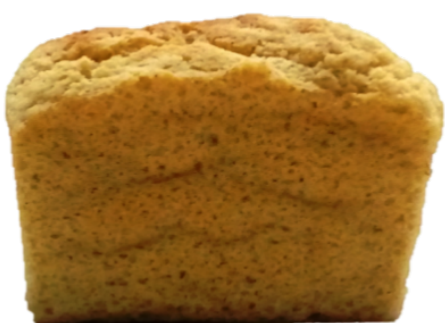

$0.5 \%$ CMC with soda (sample no. 3 )

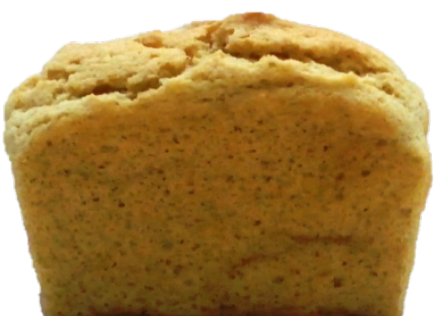

$0.7 \%$ CMC with soda (sample no. 5)
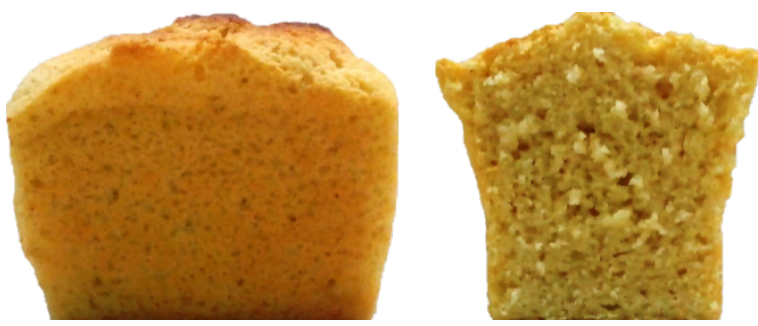

$0.3 \%$ CMC (sample no. 2)
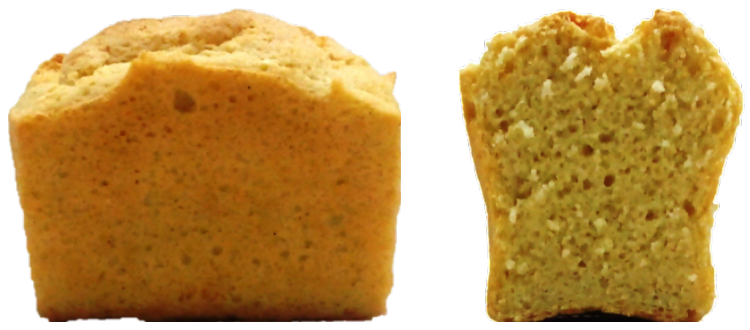

$0.5 \%$ CMC (sample no. 4)
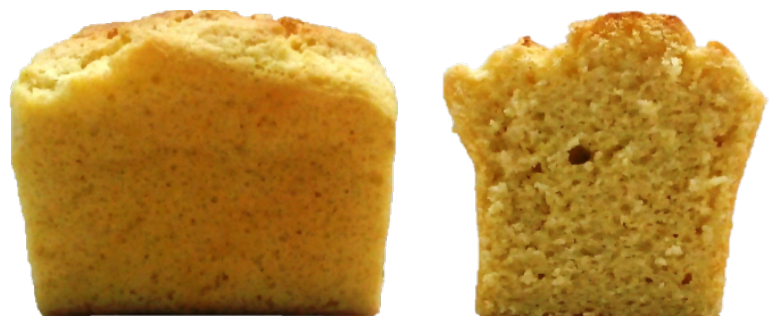

$0.7 \%$ CMC (sample no. 6)

Figure 1 Appearance (section) of gluten-free non-yeast breads with the addition of baking soda and CMC.

Table 1 Physico-chemical indices of gluten-free non-yeast breads with addition of soda and CMC $(\mathrm{n}=3, p \leq 0.05)$.

\begin{tabular}{|c|c|c|c|}
\hline No. of sample & $\begin{array}{c}\text { Type and concentration of } \\
\text { additive }\end{array}$ & $\begin{array}{l}\text { Specific volume, } \\
\mathrm{cm}^{3} .100 \mathrm{~g}^{-1}\end{array}$ & Baking loss, $\%$ \\
\hline 1 & $0.3 \%$ CMC with soda & 214 & 15.0 \\
\hline 2 & $0.3 \% \mathrm{CMC}$ & 222 & 15.0 \\
\hline 3 & $0.5 \%$ CMC with soda & 220 & 12.5 \\
\hline 4 & $0.5 \% \mathrm{CMC}$ & 236 & 12.5 \\
\hline 5 & $0.7 \%$ CMC with soda & 203 & 10.0 \\
\hline 6 & $0.7 \% \mathrm{CMC}$ & 198 & 11.3 \\
\hline
\end{tabular}

Table 2 Characterization of wetting angle $(\mathrm{n}=3, p \leq 0.05)$.

\begin{tabular}{lcc}
\multicolumn{1}{c}{ Type and concentration of additive } & \multicolumn{2}{c}{ Characterization of wetting angle } \\
& $\alpha$ & $\sin \alpha$ \\
\hline Without additives & 83 & 0.993 \\
$\mathbf{0 . 5} \%$ CMC & 80 & 0.985 \\
$\mathbf{0 . 5 \%}$ CMC+ 0.5 Scanpro T95 & 74 & 0.961 \\
$\mathbf{0 . 5} \%$ CMC+ 1.0 Scanpro T95 & 71 & 0.946 \\
$\mathbf{0 . 5 \%}$ CMC+ 1.5 Scanpro T95 & 80 & 0.985 \\
\hline
\end{tabular}




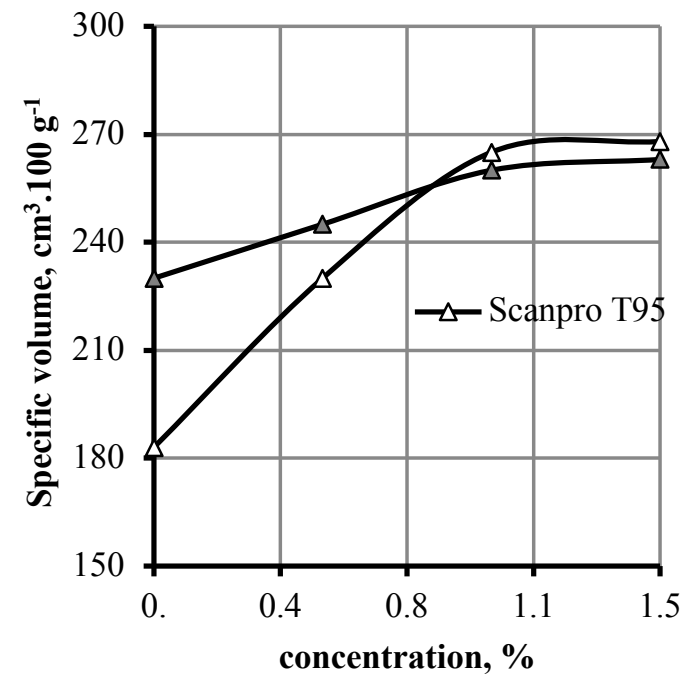

A

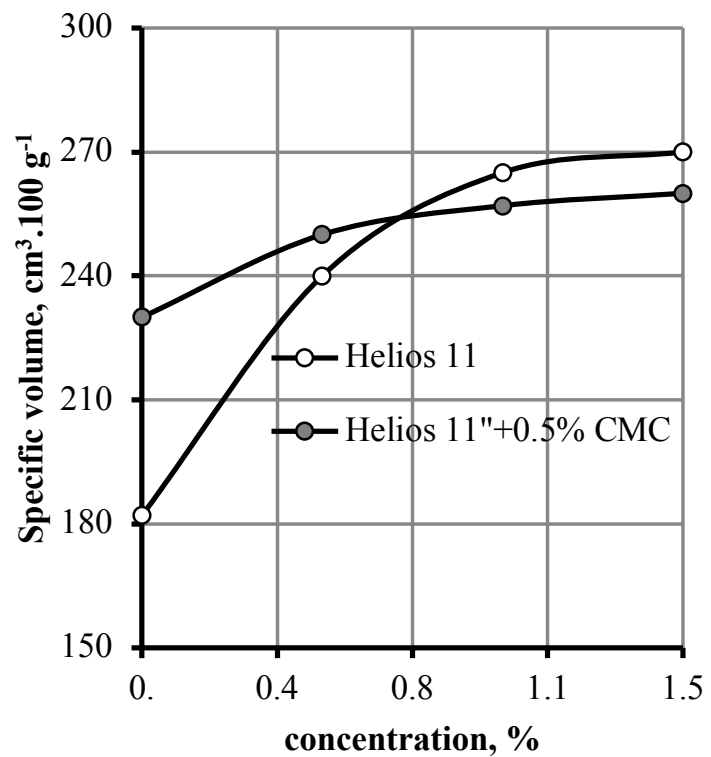

C

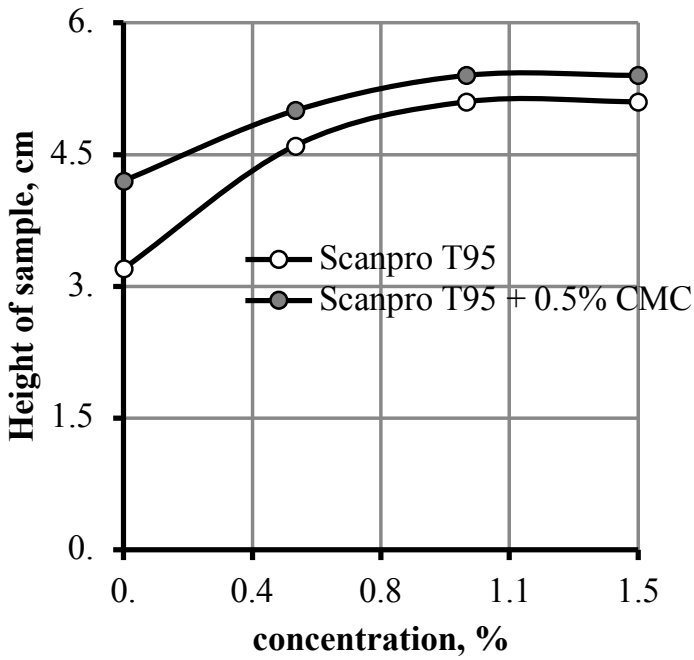

B

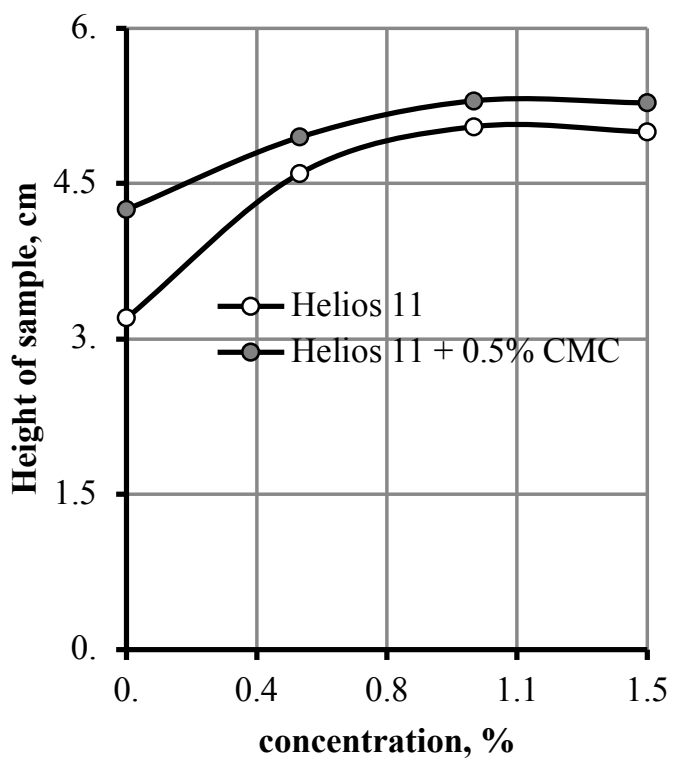

D

Figure 2 Specific volume and height of bread samples depending on concentration of animal protein concentrates (without CMC and with application of $0.5 \% \mathrm{CMC}$ ).

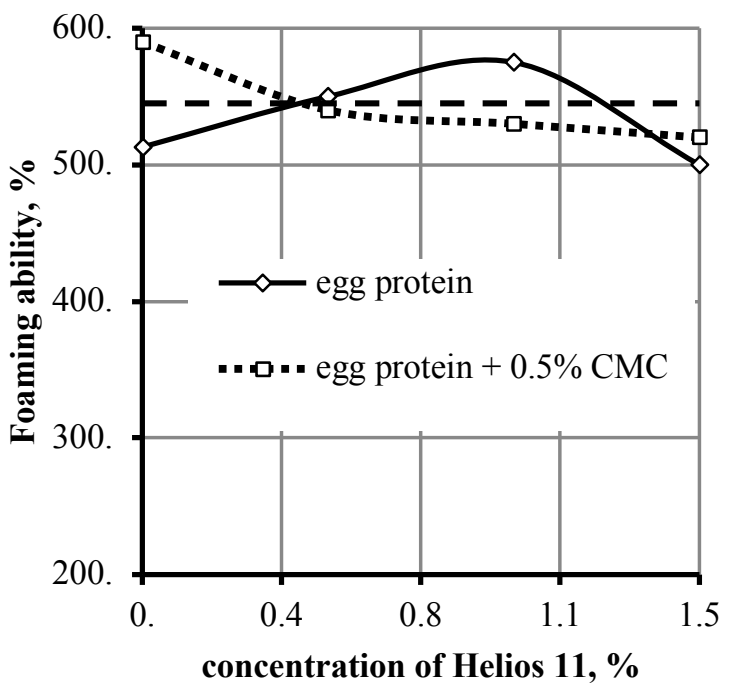

A

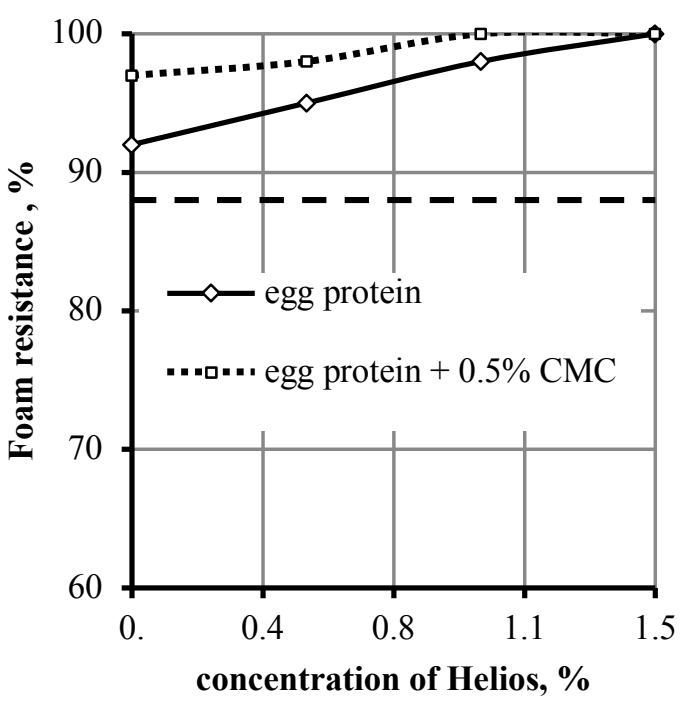

B

Figure 3 Influence of amount of APC (Helios-11) on foaming ability (a) and foam resistance (b) of egg protein without additives and with addition of $0.5 \%$ CMC solution (CMS $6500,10 \%$ by weight of egg protein). 


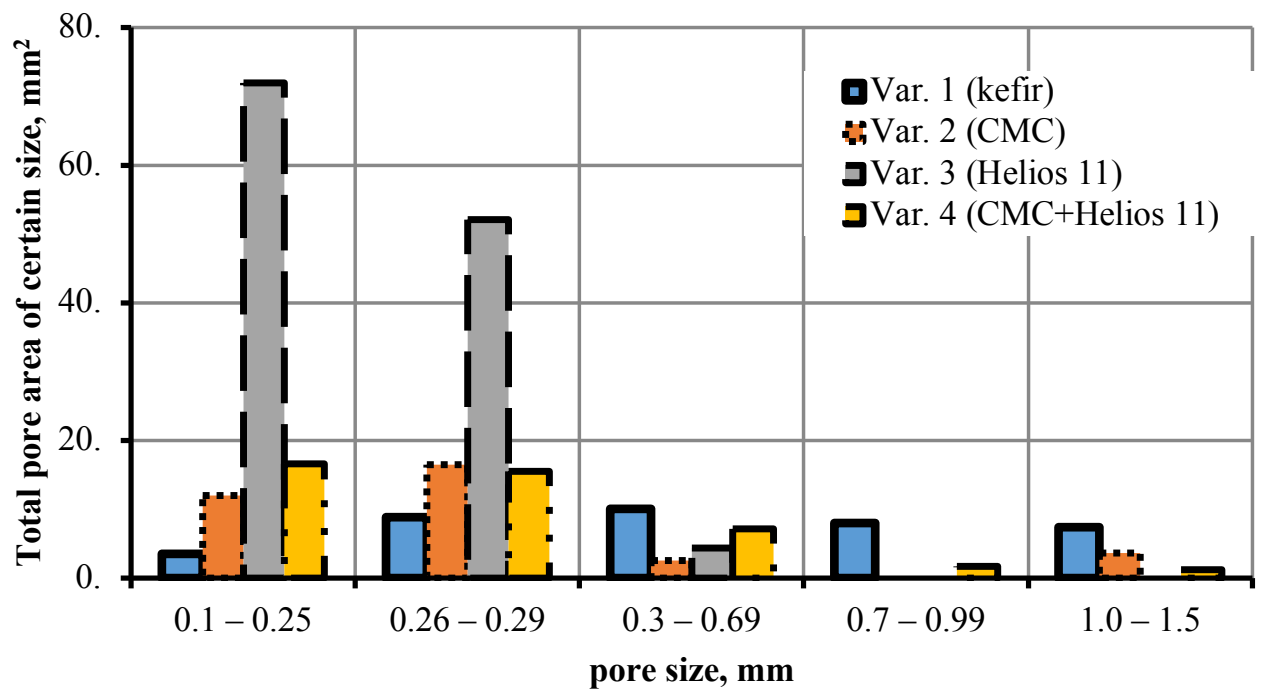

Figure 4 Total pore area of certain size of gluten-free non-yeast dough with different recipe compositions (variants 1, 2, 3 and 4).

Table 3 Results of mathematical processing of quantitative estimation of dough foam structure with different recipe compositions.

\begin{tabular}{|c|c|c|c|c|c|}
\hline \multirow[t]{2}{*}{ Indexes } & \multicolumn{5}{|c|}{ Pore diameter, mm } \\
\hline & $0.1-0.25$ & $0.26-0.29$ & $0.3-0.5$ & $0.7-1.0$ & $1.1-1.5$ \\
\hline Average area of one pore, $\mathrm{mm}^{2}$ & 0.03 & 0.07 & 0.13 & 0.57 & 1.23 \\
\hline \multicolumn{6}{|c|}{ Variant 1 (kefir) } \\
\hline Number of pores in the field of view, pes. & 117 & 127 & 77 & 14 & 6 \\
\hline Total pore area, $\mathbf{m m}^{2}$ & 3.51 & 8.89 & 10.01 & 7.98 & 7.38 \\
\hline Total dough area, $\mathbf{m m}^{2}$ & 600 & 600 & 600 & 600 & 600 \\
\hline Ratio of pore area to total area of dough, $\%$ & 0.59 & 1.48 & 1.67 & 1.33 & 1.23 \\
\hline $\begin{array}{l}\text { Ratio of total pore area to total area of dough, } \\
\%\end{array}$ & & & 6.3 & & \\
\hline \multicolumn{6}{|c|}{ Variant 2 (CMC) } \\
\hline Number of pores in the field of view, pcs. & 400 & 235 & 20 & 0 & 3 \\
\hline Total pore area, $\mathbf{m m}^{2}$ & 12 & 16.45 & 2.6 & 0 & 3.69 \\
\hline Total dough area, $\mathbf{m m}^{2}$ & 600 & 600 & 600 & 600 & 600 \\
\hline Ratio of pore area to total area of dough, $\%$ & 2 & 2.74 & 0.43 & 0 & 0.62 \\
\hline $\begin{array}{l}\text { Ratio of total pore area to total area of dough, } \\
\%\end{array}$ & & & 5.79 & & \\
\hline \multicolumn{6}{|c|}{ Variant 3 (Helios-11) } \\
\hline Number of pores in the field of view, pes. & 2400 & 744 & 34 & 0 & 0 \\
\hline Total pore area, $\mathbf{m m}^{2}$ & 72 & 52.08 & 4.42 & 0 & 0 \\
\hline Total dough area, $\mathbf{m m}^{2}$ & 600 & 600 & 600 & 600 & 600 \\
\hline Ratio of pore area to total area of dough, $\%$ & 12 & 8.68 & 0.74 & 0 & 0 \\
\hline $\begin{array}{l}\text { Ratio of total pore area to total area of dough, } \\
\%\end{array}$ & & & 24.42 & & \\
\hline \multicolumn{6}{|c|}{ Variant $4($ CMC + Helios-11) } \\
\hline Number of pores in the field of view, pes. & 552 & 221 & 55 & 3 & 1 \\
\hline Total pore area, $\mathbf{m m}^{2}$ & 16.56 & 15.47 & 7.15 & 1.71 & 1.23 \\
\hline Total dough area, $\mathbf{m m}^{2}$ & 600 & 600 & 600 & 600 & 600 \\
\hline Ratio of pore area to total area of dough, $\%$ & 2.76 & 2.58 & 1.19 & 0.29 & 0.21 \\
\hline $\begin{array}{l}\text { Ratio of total pore area to total area of dough, } \\
\%\end{array}$ & & & 7.02 & & \\
\hline
\end{tabular}




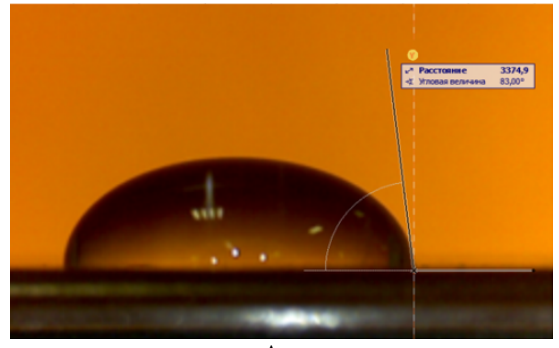

A

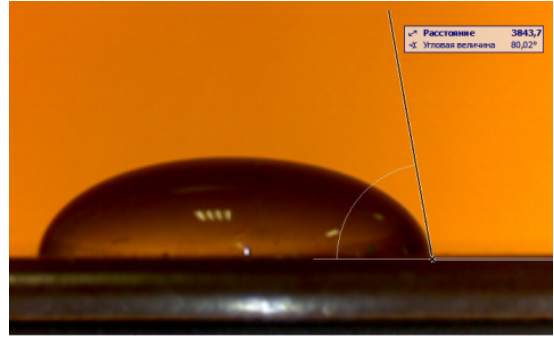

B

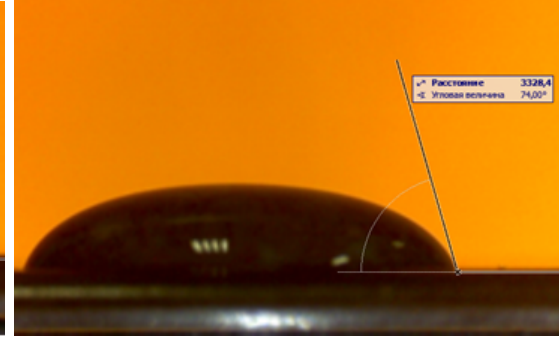

C

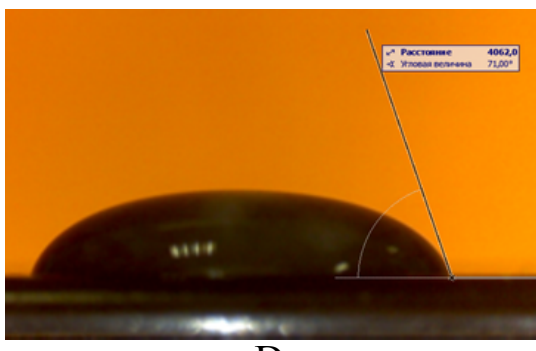

$\mathrm{D}$

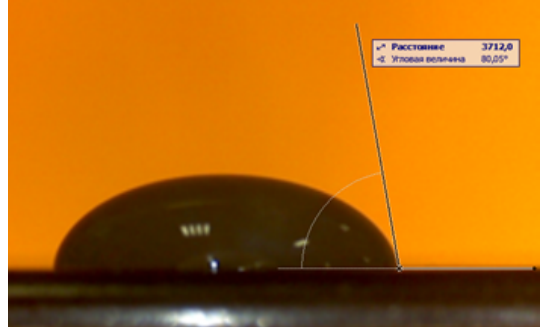

$\mathrm{E}$

Figure 5 Appearance of experimental samples - water drops with supplements: a) without supplements; b) $0.5 \%$ CMC; c) $0.5 \% \mathrm{CMC}+0.5 \%$ Scanpro T95; d) $0.5 \% \mathrm{CMC}+1.0 \%$ Scanpro T95; e) $0.5 \% \mathrm{CMC}+1.5 \%$ Scanpro T95.

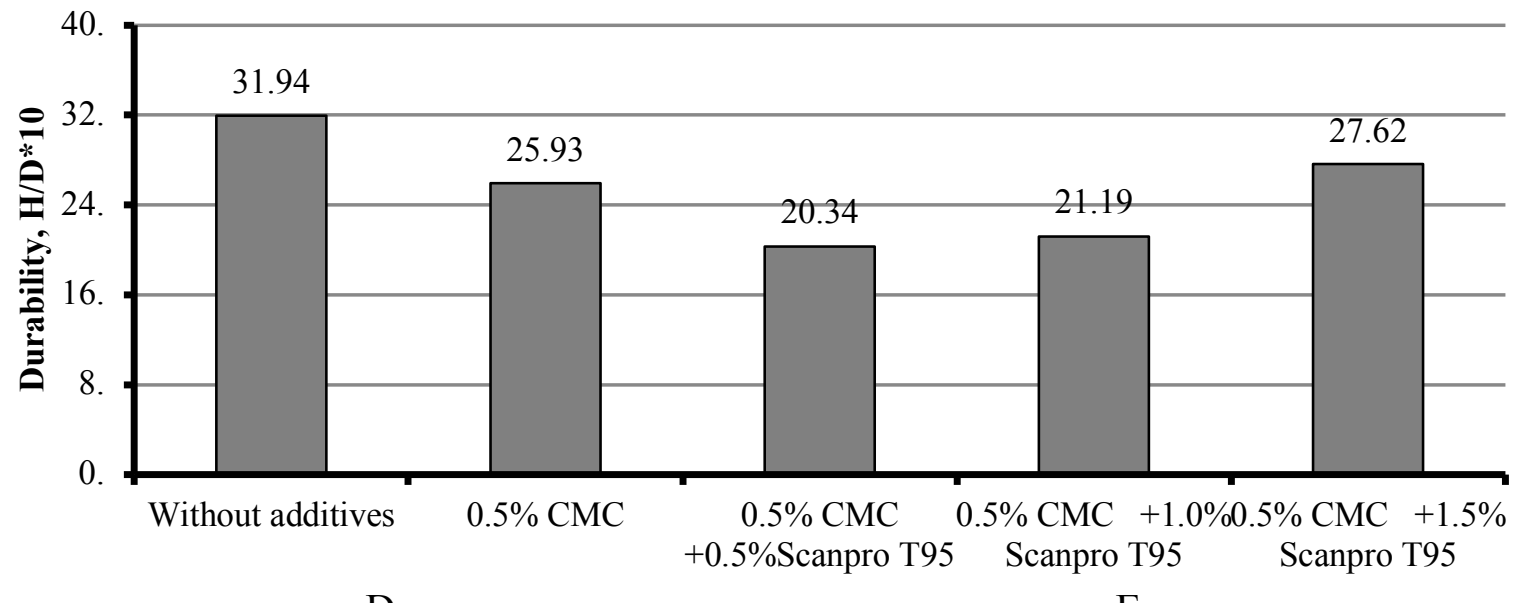

$\mathrm{D}$

$\mathrm{E}$

Figure 6 Durability of droplets of studied samples.

The graphs show that the addition of Helios in concentrations from 0.5 to $1.5 \%$ contributes to an increase in the foaming capacity of the egg protein, but the effect is extreme: with up to $1.0 \%$ of additive, the foaming capacity increases by $10-15 \%$, while with an increase in the Helios up to $1.5 \%$, the FA reduces to the control values.

In the presence of $0.5 \% \mathrm{CMC}$ solution, the influence of Helios-11 on the FA changes to the opposite - the index gradually reduces with increase of the amount of Helios- 11 , reaching $520 \%$ (which is $88 \%$ of the control value (egg whites with $0.5 \% \mathrm{CMC}$ ). The foam stability improves with the addition of Helios-11 separately and in the presence of $\mathrm{CMC}$, bringing the value closer to $100 \%$ at $1.0 \%$ Helios- 11 and $0.5 \%$ CMC solution. The FA reducing tendency of egg protein can be explained by the increase of mass density while whipping due to the ability of both additives (CMC and APC) to thicken the solution, because the dilution of a colloidal solution of egg white protein (e.g., with the addition of $10 \%$ water) increases the FA of the system, reaching $545 \%$ compared with the native protein $-500 \%$, although the foam resistance is reducing (to $88 \%$ ).

At the next stage of the study, quantitative assessment of the foam structure quality of the dough was determined. Dough samples were prepared according to the suggested variants and placed in glass cuvettes. The macrophotography method fixed the visual structure. The number and size of pores were determined using the Photo M 1.21 program, and the results of their mathematical processing are in Figure 4 and Table 3. The analysis shows that in the presence of any additive, the structure of the foam/dough changes, namely: the number of large pores (about $1 \mathrm{~mm}$ or more) reduces almost fourfold. Thus, the total area of large pores of sizes $0.7-1.5 \mathrm{~mm}$ in the dough sample according to variant 1 (without additives) is $15.36 \mathrm{~mm}^{2}$ in the field of view, and in the experimental 
samples (variants 2 and 4) is 3.69 and $2.94 \mathrm{~mm}^{2}$ respectively, while variant 3 is zero. At the same time, the number of small and very small pores (less than $0.5 \mathrm{~mm}$ ), especially in the sample with added Helios-11 (variant 3), increases significantly. The data obtained correlates with the data of the foaming capacity, which is the highest with the addition of Helios-11 (Figure 3). The foregoing shows that the suggested supplements for improving gluten-free non-yeast dough contribute to the improvement of the porosity of the foam-like structure, forming a fine, uniform foam. This effect can be explained by the ability of the additives to improve the foaming ability and foam resistance to fracture. The formulation without gluten can only retain gas if another gel replaces gluten, being important that the ingredients form a continuous phase for stabilizing gas cells (Gallagher, Gormley and Arendt, 2004; Sabanis, Lebesi and Tzia, 2009).

The substrate availability of gluten-free raw materials plays an important role for biological gas production through microorganisms, which can additionally improve the gas retention capacity by synthesizing hydrocolloids. Moreover, the deficient volume of gluten-free dough might be substantially improved by optimizing mechanical aeration via beating. High-speed mixing can provide a homogeneous distribution of small gas bubbles. Computed tomography is the method of choice to monitor gas bubbles if structure-conserving preparations and sufficient resolution are provided. To replace the traditional kneading stage, processing adaptions should provide maximum gas entrapment by mixing (Elgeti, Jekle and Becker, 2015). Porosity of gluten-free bread crumb defined by the image analysis showed significant differences with the inclusion of buckwheat flour (Wronkowska, Haros and Soral-Śmietana, 2013).

Foaming is a complex process due to the combined influence of numerous physico-chemical, physicomechanical and other factors. Regularities that characterize the process of foam formation essentially depend on the conditions of a particular technological process.

For the study of surface phenomena at the interface between phases (gas-liquid-solids), it is expedient to apply a method based on measurement of the surface tension of this section boundary, which allows very reliable data to be obtained, provided that the temperature, volume of the system and the chemical potentials of all components in both phases remain constant. The experiment results are shown in Figure 5, and the data of its processing in Table 2 and Figure 6. During the experiment, the measurement time was $10 \mathrm{~s}$ (for all samples), since even after a short period of holding samples before measurements, the shape of the drop changed.

The wetting angle (edge angle) is the main characteristic of wetting. This is the angle of inclination of the surface of the liquid to the wetted surface of the solid. The liquid itself is always inside the edge angle. The top of the wetting corner is located on the line of wetting, which passes through the contact line of the three phases. It was found that during a certain period of time, dispersal of liquid on the surface occurs. Therefore, all samples were examined in identical conditions - after 10 seconds, placing a drop on the surface.

The suggested supplements-enhancers of structure generally reduce the foam resistance, to a greater extent in the case of joint application (Figure 6). Indeed, the H/D index of the control sample is 32 , and in the presence of $0.5 \%$ CMC with addition of $0.5-1.0 \%$ of APC is $20-21$. The decrease in the efficiency of $1.5 \%$ APC can be explained by a reverse increase in the surface tension of the liquid phase of the dough (this confirms an increase in the H/D index to 27.6), which occurs due to the possible processes of gelatinization with such an amount of additives.

\section{CONCLUSION}

The results obtained show that the use of CMC at a concentration of $0.5 \%$ is appropriate. The bread volume increases by $15 \%$ compared to the control sample. Consistent use of CMC and baking soda is inappropriate, as it leads to excessive loosening of the crumb structure and frame weakening.

The positive influence of animal protein concentrates on the structural and mechanical properties of bread has been proved. For the use of APC as an enhancer of gluten-free non-yeast dough, it is necessary to limit its concentration to within $0.5-1.0 \%$ of the mass of flour (higher concentrations lead to a slight deterioration of the structural and mechanical properties of the crumb, and are also inappropriate from an economic point of view). The suggested additives for improving gluten-free non-yeast dough contribute to improving the porosity of the foamlike structure, forming a fine and uniform foam. It was established that the total area of large pores in the range of $0.7-1.5 \mathrm{~mm}$ in the variant 1 dough sample (without additives) is $15.36 \mathrm{~mm}^{2}$ in the field of view, and in the experimental samples, for variants 2 and 4 is 3.69 and $2.94 \mathrm{~mm}^{2}$, respectively, while variant 3 is zero. At the same time, the number of small and very small pores (less than $0.5 \mathrm{~mm}$ ), especially in the sample with added Helios-11 (variant 3), increases. The index of the foam resistance of the control sample is 32 , and in the presence of $0.5 \%$ CMC with additives $0.5-1.0 \%$ APC is $20-21$, which indicates a decrease in the surface tension of aqueous solutions with additives-enhancers of the structure, to a certain extent - in the case of consistent application.

Such data is in good agreement with the results of other research on the formation of an improved foamy texture of dough, and better organoleptic properties based on the results of laboratory baking, which determines the use of these additives in the indicated amounts. This also coincides with the interval recommended for effective concentrations.

\section{REFERENCES}

Aguilar, N., Albanell, E., Miñarro, B., Capellas, M. 2015. Chickpea and tiger nut flours as alternatives to emulsifier and shortening in gluten-free bread. LWT - Food Science and Technology, vol. 62, no. 1, p. 225-232. https://doi.org/10.1016/j.lwt.2014.12.045

Aguilar, N., Albanell, E., Miñarro, B., Capellas, M. 2016. Chestnut flour sourdough for gluten-free bread making. European Food Research and Technology, vol. 242, no. 10, p. 1795-1802. https://doi.org/10.1007/s00217-016-2679-z

Andersson, H, Öhgren, C, Johansson, D, Kniola, M, Stading, M 2011 Extensional flow, viscoelasticity and baking performance of gluten-free zein-starch doughs supplemented 
with hydrocolloids. Food Hydrocolloids, vol. 25, no. 6, p. 1587-1595 https://doi.org/10.1016/i.foodhyd.2010.11.028

Cappa, C., Lucisano, M., Mariotti, M. 2013. Influence of Psyllium, sugar beet fibre and water on gluten-free dough properties and bread quality. Carbohydrate Polymers, vol. 98, no. 2, p. 1657-1666. https://doi.org/10.1016/j.carbpol.2013.08.007

de la Hera, E., Martinez, M., Gómez, M. 2013. Influence of flour particle size on quality of gluten-free rice bread. $L W T$ Food Science and Technology, vol. 54, no. 1, p. 199-206. https://doi.org/10.1016/j.lwt.2013.04.019

Deora, N. S., Deswal, A., Mishra, H. N. 2014. Functionality of alternative protein in gluten-free product development. Food Science and Technology International, vol. 21, no. 5, p. 364-379. https://doi.org/10.1177/1082013214538984

Dotsenko, V., Medvid, I., Shydlovska, O., Ishchenko, T. 2019. Studying the possibility of using enzymes, lecithin, and albumen in the technology of gluten-free bread. EasternEuropean Journal of Enterprise Technologies, vol. 1, no. 11, p. 42-51. https://doi.org/10.15587/1729-4061.2019.154957

Elgeti, D., Jekle, M., Becker, T. 2015. Strategies for the aeration of gluten-free bread - A review. Trends in Food Science and Technology, vol. 46, no. 1, p. 75-84. https://doi.org/10.1016/j.tifs.2015.07.010

Gallagher, E., Gormley, T. R., Arendt, E. K. 2004. Recent advances in the formulation of gluten-free cereal-based products. Trends in Food Science and Technology, vol. 15, no. 3-4, p. 143-152. https://doi.org/10.1016/j.tifs.2003.09.012

Gorelov, V. O., Dranchuk, M. M, 2003. Vymiryuvannya poverkhnevoho natyahu chystykh ridyn i rozchyniv metodom lezhachoyi krapli (Measurement of surface tension of pure liquids and solutions of the methods of the lying drop). Quality Control Methods and Devices, vol. 10, p. 31-35. (In English) ISBN 978-83-7464-732-8.

Gómez, M., Sciarini, L. S. 2015. Gluten-Free Bakery Products and Pasta. In Arranz Sanz, E., Fernández-Bañares, F., Salvador Peña, A., Rodrigo, L., Rosell, C. M. Advances in the Understanding of Gluten Related Pathology and the Evolution of Gluten-Free Foods. OmniaScience : Barcelona, Spain, p. 565-604. https://doi.org/10.3926/oms.265

Hager, A. S., Arendt, E. K. 2013. Influence of hydroxypropylmethylcellulose (HPMC), xanthan gum and their combination on loaf specific volume, crumb hardness and crumb grain characteristics of gluten-free breads based on rice, maize, teff and buckwheat. Food Hydrocolloids, vol. 32, no. 1 ,

p.

195-203.

https://doi.org/10.1016/j.foodhyd.2012.12.021

Korus, J., Witczak, M., Ziobro, R., Juszczak, L. 2015. The influence of acorn flour on rheological properties of glutenfree dough and physical characteristics of the bread. European Food Research and Technology, vol. 240, no. 6, p. 1135-1143. https://doi.org/10.1007/s00217-015-2417-y

Kraievska, S., Stetsenko, N. 2018. Formation of the domestic market of gluten-free foods. International ScientificPractical Journal Commodities and Markets, no. 4, vol. 28, p. 36-46. https://doi.org/10.31617/tr.knute.2018(28)03

Lazaridou, A., Duta, D., Papageorgiou, M., Belc, N., Biliaderis, C. G. 2007. Effects of hydrocolloids on dough rheology and bread quality parameters in gluten-free formulations. Journal of Food Engineering, vol. 79, no. 3, p. 1033-1047. https://doi.org/10.1016/j.jfoodeng.2006.03.032

Magomedov, G., Ponomareva, E., Aleynik, I. 2008. Innovative technologies for functional non-yeast baked bakery products. Modern Problems of Science and Education. no. 1 , p. 71-72. Avaiable at: http://scienceeducation.ru/ru/article/view?id=2390
Mancebo, C. M., San Miguel, M. Á., Martínez, M. M., Gómez, M. 2015. Optimisation of rheological properties of gluten-free doughs with HPMC, psyllium and different levels of water. Journal of Cereal Science, vol. 61, p. 8-15. https://doi.org/10.1016/j.jcs.2014.10.005

Mariotti, M., Pagani, M. A., Lucisano, M. 2013. The role of buckwheat and HPMC on the breadmaking properties of some commercial gluten-free bread mixtures. Food Hydrocolloids, vol. 30, no. 1, p. 393-400. https://doi.org/10.1016/j.foodhyd.2012.07.005

Marston, K., Khouryieh, H., Aramouni, F. 2014. Evaluation of sorghum flour functionality and quality characteristics of gluten-free bread and cake as influenced by ozone treatment. Food Science and Technology International, vol. 21, no. 8, p. 631-640. https://doi.org/10.1177/1082013214559311

Marti, A., Bottega, G., Franzetti, L., Morandin, F., Quaglia, L., Pagani, M. A. 2015. From wheat sourdough to gluten-free sourdough: a nonconventional process for producing glutenfree bread. International Journal of Food Science and Technology, vol. 50, no. 5, p. 1268-1274. https://doi.org/10.1111/ijfs. 12757

Mohammadi, M., Azizi, M. H., Neyestani, T. R., Hosseini, H., Mortazavian, A. M. 2015. Development of gluten-free bread using guar gum and transglutaminase. Journal of Industrial and Engineering Chemistry, vol. 21, p. 1398-1402. https://doi.org/10.1016/j.jiec.2014.06.013

Morais, E. C., Cruz, A. G., Faria, J. A. F., Bolini, H. M. A. 2014. Prebiotic gluten-free bread: Sensory profiling and drivers of liking. LWT - Food Science and Technology, vol. 55, no. $1, \quad$ p. $248-254$. https://doi.org/10.1016/j.lwt.2013.07.014

Moreira, R., Chenlo, F., Torres, M. D, 2012. Rheology of gluten-free doughs from blends of chestnut and rice flours. Food and Bioprocess Technology, vol. 6, no. 6, p. 1476-1485. https://doi.org/10.1007/s11947-012-0927-1

Morreale, F., Garzón, R., Rosell, C. M. 2018. Understanding the role of hydrocolloids viscosity and hydration in developing gluten-free bread. A study with hydroxypropylmethylcellulose. Food Hydrocolloids, vol. 77, p. 629-635. https://doi.org/10.1016/j.foodhyd.2017.11.004

Naumova, O., Doncova, O., Agramakova, N. 2017. Prospects for increasing the responsibility of domestic producers of gluten-free food products using the European licensing system (TM "Perekreshennyi Kolosok"). Business Inform. no. 12. p. 325-330. Available at: http://nbuv.gov.ua/UJRN/binf_2017_12_50

Nitcheu Ngemakwe, P. H., Le Roes-Hill, M., Jideani, V. A. 2014. Advances in gluten-free bread technology. Food Science and Technology International, vol. 21, no. 4, p. 256276. https://doi.org/10.1177/1082013214531425

Pal, S., McKay, J., Jane, M., Ho, S. 2019. Using Psyllium to prevent and treat obesity comorbidities. In Watson, R. R. Nutrition in the Prevention and Treatment of Abdominal Obesity. $2^{\text {nd }}$ ed. Academic Press, p. 245-260. https://doi.org/10.1016/B978-0-12-816093-0.00019-7

Pontieri, P., Mamone, G., de Caro, S., Tuinstra, M. R., Roemer, E., Okot, J., de Vita, P., Ficco, D. B. M., Alifano, P., Pignone, D., Massardo, D. R., Del Giudice, L. 2013. Sorghum, a healthy and gluten-free food for celiac patients as demonstrated by genome, biochemical, and immunochemical analyses. Journal of Agricultural and Food Chemistry, vol. 61, no. 10, p. 2565-2571. https://doi.org/10.1021/jf304882k

Phongthai, S., D'Amico, S., Schoenlechner, R., Rawdkuen, S. 2016. Comparative study of rice bran protein concentrate and egg albumin on gluten-free bread properties. Journal of 
Cereal Science, vol. 72, p. 38-45. https://doi.org/10.1016/i.jcs.2016.09.015

Puppin Zandonadi, R., Braz Assunção Botelho, R., Coelho Araújo, W. M. 2009. Psyllium as a substrate for Gluten in bread. Journal of the American Dietetic Association, vol. 109, no. 10 , p.

1781-1784.

https://doi.org/10.1016/j.jada.2009.07.032

Renzetti, S., Rosell, C. M. 2016. Role of enzymes in improving the functionality of proteins in non-wheat dough systems. Journal of Cereal Science, vol. 67, p. 35-45. https://doi.org/10.1016/j.jcs.2015.09.008

Rizkalla Reilly, N., Green, P. H. R. 2012. Epidemiology and clinical presentations of celiac disease. Seminars in Immunopathology, vol. 34, no. 4, p. 473-478. https://doi.org/10.1007/s00281-012-0311-2

Rosell, C. M., Bajerska, J., El Sheikha, A. F. 2015. Bread and its Fortification: Nutrition and Healthy Benefits. CRC Press, 320 p. ISBN 9781498701563.

Ruttarattanamongkol, K., Wagner, M. E., Rizvi, S. S. H. 2011. Properties of yeast free bread produced by supercritical fluid extrusion (SCFX) and vacuum baking. Innovative Food Science and Emerging Technologies, vol. 12, no. 4, p. 542550. https://doi.org/10.1016/j.ifset.2011.07.006

Sabanis, D., Lebesi, D., Tzia, C. 2009. Effect of dietary fibre enrichment on selected properties of gluten-free bread. LWT - Food Science and Technology, vol. 42, no. 8, p. 13801389. https://doi.org/10.1016/j.lwt.2009.03.010

Scherf, K. A., Poms, R. E. 2016. Recent developments in analytical methods for tracing gluten. Journal of Cereal Science, vol. 67, p. 112-122. https://doi.org/10.1016/j.jcs.2015.08.006

Schober, T. J., Bean, S. R., Tilley, M., Smith, B. M., Ioerger, P. 2011. Impact of different isolation procedures on the functionality of zein and kafirin. Journal of Cereal Science, vol. 54, no. 2, p. 241-249 https://doi.org/10.1016/i.jcs.2011.06.007

Tikhomirov, V. K. 1975. Foam. Theory and practice of its getting and destruction. Moscow: Chemistry. 264 p. Available at: https://www.chipmaker.ru/files/file/12930/

Trappey, E. F., Khouryieh, H., Aramouni, F., Herald, T. 2014. Effect of sorghum flour composition and particle size on quality properties of gluten-free bread. Food Science and Technology International, vol. 21, no. 3, p. 188-202. https://doi.org/10.1177/1082013214523632

Ukrainian Coeliac Society. 2019. Signing of the first licensing agreement for the use of TM "Crossed colossus". Available at: https://celiac-ukraine.com/kratkie-novosti/pdpisannya-pershogo-l-tsenz-ynogo-dogovoru-na-

vikoristannya-tm-perekresleniy-kolosok

WGO. 2016. WGO Practice Guideline - Celiac Disease. Available

http://www.worldgastroenterology.org/guidelines/globalguidelines/celiac-disease/celiac-disease-english

Wronkowska, M., Haros, M., Soral-Śmietana, M. 2013. Effect of Starch Substitution by Buckwheat Flour on GlutenFree Bread Quality. Food and Bioprocess Technology, vol. 6, no. 7, p. 1820-1827. https://doi.org/10.1007/s11947-012$\underline{0839-0}$

Ziobro, R., Witczak, T., Juszczak, L., Korus, J. 2013. Supplementation of gluten-free bread with non-gluten proteins. Effect on dough rheological properties and bread characteristic. Food Hydrocolloids, vol. 32, no. 2, p. 213-220. https://doi.org/10.1016/j.foodhyd.2013.01.006
Contact address:

Olga Shanina, Kharkiv Petro Vasylenko National Technical University of Agriculture, Department of Technologies of Processing and Food Industries, Alchevsky str., 44, 61002, Kharkiv, Ukraina, Tel.: +380509103205,

E-mail: o.shanina.ua@gmail.com

ORCID: https://orcid.org/0000-0003-2465-1257

Ivan Galyasnyj, Kharkiv Petro Vasylenko National Technical University of Agriculture, Department of Technologies of Processing and Food Industries, Alchevsky str., 44, 61002, Kharkiv, Ukraina, Tel.: +380577730149 ,

E-mail: ivangalyasnyi@yandex.ru

ORCID: https://orcid.org/0000-0002-4195-9694

Tetyana Gavrysh, Kharkiv Petro Vasylenko National Technical University of Agriculture, Department of Technologies of Processing and Food Industries, Alchevsky str., 44, 61002, Kharkiv, Ukraina, Tel.: +380577164139 ,

E-mail: gavrishtanya@ukr.net

ORCID: https://orcid.org/0000-0002-0000-0000

Kateryna Dugina, Kharkiv Petro Vasylenko National Technical University of Agriculture, Department of Technologies of Processing and Food Industries, Alchevsky str., 44, 61002, Kharkiv, Ukraina, Tel.: +380577164139 ,

E-mail: ekaterina_dygina@mail.ru

ORCID: https://orcid.org/0000-0001-7212-6428

Yuriy Sukhenko, National University of Life and Environmental Sciences of Ukraine, Department of Processes and Equipment for Processing of Agricultural Production, Heroiv Oborony str, 15, 03041, Kyiv, Ukraine, Tel.: +380675012335,

E-mail: suhenko@ukr.net

ORCID: http://orcid.org/0000-0002-1964-7467

*Vladyslav Sukhenko, National University of Life and Environmental Sciences of Ukraine, Department of Standardization and Certifying of Agricultural Products, Heroiv Oborony str, 15, 03041, Kyiv, Ukraine, Tel.: +380679912194,

E-mail: vladsuhenko@gmail.com

ORCID: http://orcid.org/0000-0002-8325-3331

Natalia Miedviedieva, National University of Life and Environmental Sciences of Ukraine Department of Standardization and Certifying of Agricultural Products, Heroiv Oborony str, 15, 03041, Kyiv, Ukraine, Tel.: +380994834450 ,

E-mail: natalya.miedvedeva@gmail.com

ORCID: http://orcid.org/0000-0002-9475-0990

Mikhailo Mushtruk, National University of Life and Environmental Sciences of Ukraine, Department of Processes and equipment for Processing of Agricultural Production, Heroiv Oborony str, 15, 03041, Kyiv, Ukraine, Tel.: +380989412606,

E-mail: mixej.1984@ukr.net

ORCID: https://orcid.org/0000-0002-3646-1226 
Tatyana Rozbytska, National University of Life and Environmental Sciences of Ukraine Department of Standardization and Certifying of Agricultural Products, Heroiv Oborony str, 15, 03041, Kyiv, Ukraine, Tel.: +380939219680,

E-mail: roirf1991@gmail.com

ORCID: https://orcid.org/0000-0003-0098-927X
Natalia Slobodyanyuk, National University of Life and Environmental Sciences of Ukraine Department of Standardization and Certifying of Agricultural Products, Heroiv Oborony str, 15, 03041, Kyiv, Ukraine, Tel.: +380982768508,

E-mail: slob2210@ukr.net

ORCID: https://orcid.org/0000-0002-7724-2919

Corresponding author: * 